International Journal of Current Advanced Research

ISSN: O: 2319-6475, ISSN: P: 2319 - 6505, Impact Factor: SJIF: 5.995

Available Online at www.journalijcar.org

Volume 6; Issue 4; April 2017; Page No. 3277-3278

DOI: http://dx.doi.org/10.24327/ijcar.2017.3278.0246

Research Article

\title{
A STUDY TO ASSESS THE KNOWLEDGE REGARDING ORGAN DONATION AMONG B.SC NURSING STUDENTS (I YEAR) AT SREE BALAJI COLLEGE OF NURSING CHROMPET, CHENNAI
}

\author{
Uma Maheswari S
}

Sree Balaji College of Nursing, Bharath University, Chrompet, Chennai

\section{A R T I I C L E $\quad$ I N $\mathbf{N}$ F}

\section{Article History:}

Received $8^{\text {th }}$ January, 2017

Received in revised form $10^{\text {th }}$ February, 2017

Accepted 22 $2^{\text {nd }}$ March, 2017

Published online $28^{\text {th }}$ April, 2017

\section{Key words:}

Knowledge, Organ, Organ donation,

Donor, Recipient

\begin{abstract}
A B S T R A C T
Organ donation is the gift of one's body parts, from a person who has recently died, or from a living donor, for the purpose of transplantation. Transplantation is an operation, which involves the replacement of diseased and defective organs and tissues with healthy ones from donors. This transplant treatment aims at saving patient that can only be saved with the organ transplantation surgery. A Study was conducted to assess the knowledge regarding organ donation among B.Sc nursing students I year. The findings were $(60 \%)$ have inadequate knowledge, (33\%) have moderate knowledge and $(7 \%)$ of them has adequate knowledge.
\end{abstract}

Copyright $\mathrm{C} 2017$ Uma Maheswari S. This is an open access article distributed under the Creative Commons Attribution License, which permits unrestricted use, distribution, and reproduction in any medium, provided the original work is properly cited.

\section{INTRODUCTION}

Organ Donation is where a person offers their organ for transplant. Their organ are given to someone who has damaged organs that need to be replaced.An Organ Transplant may save a person's life or it may significantly improve their health and quality of life.

Organ Donation Day is observed every year on 13th of August. Due to lack of awareness, there are myths and fears in people's mind about organ donation. Donation of organ and tissue is the ultimate humanitarian act of charity and there are no age limits on who can be organ donor, as long as the person is healthy enough. The commonly transplanted organs are kidneys, heart, liver, lungs and pancreas while the transplantable tissues are Eye Cornea, Bone, Skins and Heart Valves. Thus a single donor can save the lives of a number of people. The experiments of organ transplantation in animals and humans' body began in the 18th century. There are numerous failures experienced by the scientists over the years. The successful organ transplant had been done by the mid of 20th century.

\section{Facts about Organ Donation}

- Anybody can be an organ donor irrespective of their age, caste, religion, community etc

- There is no defined age for donating organs. The decision to donate organs is based on strict medical criteria, not age.

*Corresponding author: Uma Maheswari S

Sree Balaji College of Nursing, Bharath University,

Chrompet, Chennai
- Tissues such as cornea, heart valves, skin, and bone can be donated in case of natural death but vital organs such as heart, liver, kidneys, intestines, lungs, and pancreas can be donated only in the case of 'brain death'.

- Organs such as the heart, pancreas, liver, kidneys and lungs can be transplanted to those recipients whose organs are failing because it allows many recipients to return to a normal lifestyle.

- Anyone younger than age 18 needs to have the agreement of a parent or guardian to be a donor.

\section{METHODS}

This present study was conducted at Sree Balaji college of Nursing, Chennai. The sample for this study consists 30 students from first year b.sc nursing. The instrument used for collection of data was a questionnaire method in English to assess the knowledge of students regarding organ donation. The questionnaire was set out are age, Sex, religion, type of family, total family income, and Source of health information.

\section{RESULT}

The study findings revealed that,

- The majority of $16(54 \%) 18$ years, $10(33 \%) 17$ years and $4(13 \%)$ of 19 years respectively.

- There were $30(100 \%)$ of female.

- The majority of $26(87 \%)$ of Hindu and 4 (13\%) of Christian.

- There were $22(73 \%)$ of nuclear family and $8(27 \%)$ of joint family. 
- The majority $8(27 \%)$ of their income were Rs.5000Rs.7000, 10(33\%) of their income were Rs.7000-Rs.10, $000,9(30 \%)$ of their income were above Rs.10, 000 and $3(10 \%)$ of their income were below Rs. 5000.

- Majority of source of information were through media $14(47 \%)$, through news paper 6(20\%), through 6(20\%) health professional and $4(13 \%)$ through neighbours and relatives.

- Majority (60\%) have inadequate knowledge, (33\%) have moderate knowledge and $(7 \%)$ of them have adequate knowledge.

\section{Percentage Distribution of Level of Knowledge}

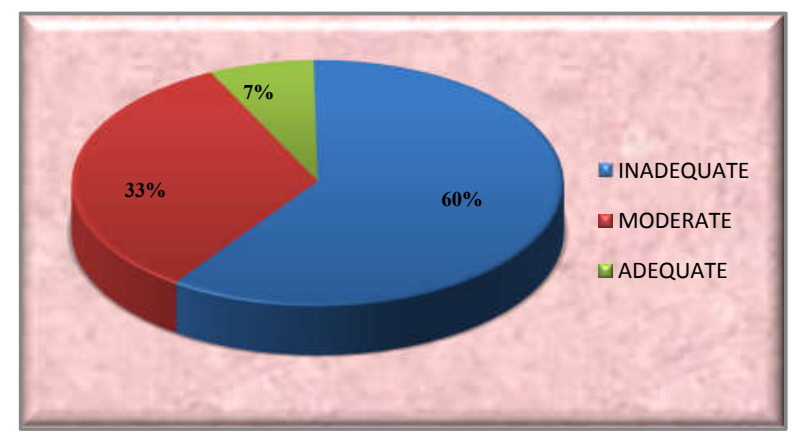

Majority $18(60 \%)$ of them had inadequate knowledge, 10 (33\%) had moderate knowledge and $2(7 \%)$ had inadequate knowledge.

\section{CONCLUSION}

The present study was conducted to "Assess the knowledge regarding organ donation among b.sc nursing students (I year) at Sree Balaji College of nursing chrompet, Chennai. A total number of 30 students who met the criteria were selected by convenient sampling technique. After the selection of samples, the interview was conducted with the structured questionnaire being distributed to the 30 students regarding organ donation.

\section{Recommendation}

The sample study can be conducted in schools, hospital, offices etc.

Frequent awareness programmers are essential among adolescents on organ donation.

\section{Bibilography}

1. Bardell T, Hunter DJ, Kent WD, Jain MK. Do medical students have knowledge needed to maximize organ donation rates? Canadian Journal of Surgery, 2003; 46(6):453-7.

2. Mishra PH, Vij A, Sarma RK. A knowledge, attitude and practice study of organ donation and its problems in the metropolitan city of Delhi. Journal of the Academy of Hospital Administration 2004; 16(1):1-6.

3. Rithalia A, McDavid C, Suekarran S, Myers L. Impact of presumed consent for organ donation on donation rates. British Medical Journal 2009; 338.

4. Schaeffner ES, Windisch W, Freidel K, Breitenfeldt K, Winkelmayer WC. Knowledge and attitude regarding organ donation among medical students and physicians. Clinical Transplantation 2004; 77(11):1714-8.

5. Collins TJ. Organ and tissue donation: a survey of nurse's knowledge and educational needs in an adult ITU. Intensive and Critical Care Nursing, 2005; 21(4):226-33.

6. Roark D. Overhauling the organ donation system. American Journal of Nursing 2000; 6:44-9.

7. Koul L. Methodology of educational research. New Delhi: Vikas publishing house Pvt Ltd; 2004.

8. Polit DF, Hungler BP. Nursing research: principles and methods. Philadelphia: Lippincott; 2000.

9. Kozier B, Glenora E. Fundamentals of nursing standards and practice. California: Mosby Publication; 2004.

10. Collins TJ. Organ and tissue donation: a survey of nurse's knowledge and educational needs in an adult ITU: Intensive and Critical Care Nursing, 2005; 21(4):226-33.

11. Jones-Riffell AJ, Stoeckle ML. Attitudes of upper division nursing students toward organ donation. Journal of Continuing Education of Nursing.1998; 29(6):274-81

\section{How to cite this article:}

Uma Maheswari S (2017) ' A Study To Assess The Knowledge Regarding Organ Donation Among B.Sc Nursing Students (I Year) At Sree Balaji College Of Nursing Chrompet, Chennai', International Journal of Current Advanced Research, 06(04), pp. 3277-3278.

DOI: http://dx.doi.org/10.24327/ijcar.2017.3278.0246 